\title{
THE APPLICATION OF PROBLEM SOLVING APPROACH IN IMPROVING JUNIOR HIGH SCHOOL STUDENTS' MATHEMATICAL COMMUNICATION AND DISPOSITION SKILL
}

\author{
Imas Mulyasari ${ }^{1}$, Euis Eti Rohaeti ${ }^{2}$, Asep Ikin Sugandi ${ }^{3}$ \\ ${ }^{1}$ SMPN 2 Subang \\ ${ }^{1,2,3}$ IKIP Siliwangi, Cimahi \\ 1mulyasari569@gmail.com, ${ }^{2}$ e2rht@ikipsiliwangi.ac.id, ${ }^{3}$ asepikinsugandi@gmail.com
}

Received: Jul 16 $6^{\text {th }}, 2018$; Accepted: Sep $26^{\text {th }}, 2018$

\begin{abstract}
This article is derived from the research result entitled "The Application of Problem Solving Approach in Improving Junior High School Students' Mathematical Communication and Disposition Skill”. The research is purposed to see and analyze if there are some improvements in mathematical communication and disposition skill achievement of the students who have been treated using problem solving approach compared to the students who are still treated using conventional approach. The population of the research is all students at a junior high school in Subang regency. Out of these students, 40 students of class VIII D were chosen randomly as the experiment class, and 41 students of class VIII C have also been randomly chosen as the control class. The data in this research have then been analyzed using parametric and non-parametric statistic. The result of this analysis has shown that the achievement of experiment class students' mathematical communication and disposition skill is better than the achievement of the control class students. The experiment class students' mathematical disposition is also better than those of the control class. Lastly, the result also shows that there is some kind of correlation between the mathematical communication and mathematical disposition on the level of medium.
\end{abstract}

Keywords:Problem Solving Approach, Mathematical Communication, Mathematical Disposition

\begin{abstract}
Abstrak
Penelitian ini bertujuan untuk mengetahui dan menelaah pencapaian dan peningkatan kemampuan komunikasi dan disposisi matematik siswa yang mendapatkan pembelajaran dengan pendekatan problem solving lebih baik daripada siswa yang mendapatkan pembelajaran biasa. Populasi dari penelitian ini adalah siswa di salah satu SMP di Kabupaten Subang, dengan subjek sampelnya adalah 40 siswa kelas VIII D sebagai kelas eksperimen dan 41 siswa kelas VIII D sebagai kelas kontrol yang ditetapkan secara acak. Data dalam penelitian ini di analisis dengan statistik parametrik dan non parametrik. Hasil penelitian menunjukkan bahwa pencapaian dan peningkatan kemampuan komunikasi matematik siswa SMP yang mendapat pembelajaran dengan pendekatan problem solving lebih baik daripada siswa yang mendapat pembelajaran biasa. Disposisi matematik siswa SMP yang pembelajarannya menggunakan pendekatan problem solving lebih baik daripada yang pembelajarannya menggunakan pembelajaran biasa. Terdapat kaitan antara komunikasi dengan disposisi matematik dengan kriteria sedang.
\end{abstract}

Keywords: Pendekatan Problem Solving, Komunikasi Matematik, Disposisi Matematik

How to Cite: Mulyasari, I., Rohaeti, E.E., Sugandi, A.I. (2018). The Application of Problem Solving Approach in Improving Junior High School Student's Mathematical Communication and Disposition Skill. JIML, 1 (3), 295-301. 

Skill

\section{INTRODUCTION}

The objective of mathematics learning stated that mathematics learning should be able to help students understand the concept, solve systematical problems, relate mathematics and daily life, and state mathematical ideas both orally and writtenly. Therefore, to achieve the objective of mathematics learning, the learning process needs to be paid attention more seriously. As one of the anticipacical steps, a serious effort of beautifying mathematics learning needs to be emphasized early on. This effort is some kind of initiative move to make students more interested and motivated in learning mathematics which will hopefuly affect their mathematical achievements. This will be materialized if the students have no obstacles in learning mathematics.

Mathematical communication is an important asset in solving, exploring, and investigating mathematics. Mathematical communication may also be said as a vessel of social activities, ideas and findings sharing, opinion sharing, evaluating and sharpening ideas to convince others. Baroody (1993) stated in Ansari (2004) stated that at least there are two important reasons why communication in mathematics learning needs to be developed at school. The first reason is that mathematics is not only a thinking, shape finding, problem solving, and decision taking tools, but mathematics is also a tool to communicate various ideas clearly, appropriately, and briefly. Second reason is that mathematics is some kind of social activity in learning. This means that mathematics is some kind of interaction mode and communication means between students, and between teacher and students.

However, in the reality students still have not acquired high mathematical communication skill. This can be seen when the students are not able to explain and translate their daily occasions into mathematical language and terms. They find it difficult to express their ideas both in oral and written forms. Additionally, they also find it difficult to add something into an information of a problem faced. Rohaeti (2004) found that students' average skill in mathematical communication's on the level of low and needs to be greatly improved.

Some conditions at schools show that the teachers of mathematics pay little attention to the improvement of students' activities in learning. Most of the students seem to follow each explanations and informations given by the teacher well. Students are rarely asking the teacher that makes the teacher is enjoying his/her time in explaining and the students are only receiving whatever the teacher says in fornt of the class. The lesson tends to be one way and teacher-dominated. There is a little and even no interaction between students and between teacher and students. This thing takes effect on the students' positive attitude toward mathematics, their curiousity, and their confidence in valuing a correlation between mathematics and others' situation.

Mathematical disposition is students' attitude in problem solving. The better students' mathematical disposition in facing a problem is, the better students' achievement will be and it will form their thinking-well habitual. Disposition is a very important component, because the students will be accostumed to face problems that need positive attitude, passion, desire, and persistance in solving them. With insufficient good disposition, the students will not be able to get desired competention. The well disposition treatment has a strong correlation with the mathematical skill. The better students' mathematical disposition is, the better students' thinking habitual will be and will hopefuly affect their mathematical achievement. This is in line with what Sugilar (2013) stated that, "mathematical disposition is one of the suporting factors in students" mathematical learning achievement." However, students' mathematical disposition potency has not been fully acquired, even now.

Efforts in improving students' mathematical communication and disposition need to be found. One of these efforts may be in form of creating lesson's atmosphere, which encourages students' enthusiasm in learning, so that the students will be more active in discussion, will be able to explain their learning's results, and will be able to relate the material with another situation or their real life. To create good lesson's atmosphere, choosing the appropriate learning approach should be done. So many learning approaches with their respective advantages. One of these approaches is problem solving approach. Sumarmo (2002) explained that problem solving in mathematics learning is both approach and goal that need to be achieved. As an approach, problem solving is used to find and comprehend 
mathematical concept. Meanwhile as a goal, the students are hoped to be able to identify known and most asked mathematical elements, to formulate mathematical or non-mathematical problems from daily situations (either old or new), to explain or interpret the result from the problems formulated, to arrange mathematical model and solve it for the real problems, and use mathematics meaningfully. Based on the identification above, the researcher is interested to use the problem solving approach to improve the junior high school level students' mathematical communication and disposition skill.

\section{METHOD}

The method used in this research is quasi-experiment. Two classes were involed, namely experiment and control class. The experiment class was treated using problem solving approach, while the control class was treated using the conventional approach. According to the method, this study is pre-test post-test group control research, which involves two groups random sampling.

The population of this research is the students at a junior high school in Subang regency. The sample of this research is 40 students of VIII D as experiment class, and 41 students of VIII C of control class which was set randomly. Both of the sample classes were given the material of Linear Equations of One Variable (Persamaan Linear Satu Variabel (PLSV)). The instrument of this research is the qualitative and quantitative data.

\section{RESULT AND DISCUSSION}

\section{Results}

The obtained and analyzed data in this research is the result data of pre-teset, post-test, and observational sheets of junior high school level students' mathematical communication and disposition skill in both experiment and control class.

Based on the result of pre-test, post-test, and normalized N-gain analysis of mathematical communication skill, it is obtained the average score $(\dot{x})$ from the ideal score and the standard deviation (sd). The data can be seen in Table 1 as follows:

Table 1. The Description of the Mathematical Communication Skill Result

\begin{tabular}{|c|c|c|c|c|c|c|c|}
\hline \multirow{2}{*}{ Ability } & & \multicolumn{3}{|c|}{ Problem SolvingApproach } & \multicolumn{3}{|c|}{ Conventional } \\
\hline & & Pretest & Posttest & N-Gain & Pretest & Posttest & N-Gain \\
\hline Communication & $\bar{x}$ & 4,43 & 15,18 & \multirow{2}{*}{0,48} & 4,85 & 11,32 & \multirow{2}{*}{0,29} \\
\hline & $\mathrm{sd}$ & 2,46 & 5,54 & & 2,07 & 5,27 & \\
\hline
\end{tabular}

Explanation : $\quad$ The Ideal Score of Mathematical Communication Skill $=27$

The average post-test value result of mathematical communication skill of the experiment class is 15.18 , while the control class is 11.32 . The $\mathrm{N}$-Gain of the experiment class is 0.48 , while the control class is 0.29 . This means that the N-Gain of the class which uses problem solving approach is bigger than the class which uses conventional approach.

The normalized N-Gain is purposed to know how big the improvement of students' comprehension is. The N-Gain result of both classes can be seen in the Table 2 as follows:

Table 2. The N-Gain Statistical Description Data of Mathematical Communication Skill

\begin{tabular}{ccccc}
\hline \multirow{3}{*}{ N-Gain } & Class & N & Mean & Sd \\
\cline { 2 - 5 } & Experiment & 40 & 0,48 & 0,23 \\
\cline { 2 - 5 } & Control & 41 & 0,29 & 0,23 \\
\hline
\end{tabular}

Based on table 2 above, it is clearly seen that the N-Gain of students' mathematical communication skill which were treated using problem solving approach with $\mathrm{g}=0.48$ is higher than those which use conventional approach with $g=0.29$. However, both of them are still in the level of low.

Table 3. The Description of Mathematical Disposition Posttest

\begin{tabular}{cccc}
\hline & & PSA Approach & Conventional \\
\hline Disposition & $\mathrm{x}$ & 88,03 & 82,98 \\
\hline & $\mathrm{Sd}$ & 7,61 & 5,59 \\
\hline
\end{tabular}


298 Mulyasari, Rohaeti, \& Sugandi, The Application of Problem Solving Approach in Improving Junior High School Student's Mathematical Communication and Disposition Skill

From table 3 above it can be said that the students' mathematical disposition of experiment class with $X^{\prime}=88.03$ is higher than the control class with $X=82.98$. In other words, the students who were treated using problem solving approach have better mathematical disposition than those who were treated using conventional approach.

To find out if there is any mathematical disposition effect to the students' mathematical communication skill, the linear regression test was conducted. To see the regression equation, we can take a look at the table below:

Table 4. The Regression Equation of Mathematical Communication and Disposition Skill Coefficients

\begin{tabular}{llccccc}
\hline \multirow{2}{*}{ Model } & \multicolumn{2}{c}{$\begin{array}{c}\text { Unstandardized } \\
\text { Coefficients }\end{array}$} & $\begin{array}{c}\text { Standardized } \\
\text { Coefficients }\end{array}$ & t & Sig. \\
\cline { 3 - 6 } & & B & Std. Error & Beta & & \\
\hline \multirow{2}{*}{1} & $-22,805$ & 8,401 & & $-2,715$ & 0,010 \\
\cline { 2 - 6 } & (Constant) & 0,431 & 0,095 & 0,593 & 4,537 & 0,000 \\
\hline
\end{tabular}

$\mathrm{Y}=-22.805+0.431 \mathrm{X}$

With: $\quad \mathrm{Y}=$ Mathematical Communication Skill

$\mathrm{X}=$ Mathematical Disposition

$\mathrm{a}=-22.805$

$\mathrm{b}=0.431$

Interpretation:

1) $b=0.431$ means that students' mathematical disposition has positive result to the students' mathematical communication skill. This also means that the bigger students' mathematical disposition is, the bigger students' mathematical communication will be.

2) $\mathrm{A}=-22.895$ means that if someone doesn't have any mathematical disposition, then his/her mathematical communication skill is -22.895 with the assumption that the other variables that affect are considered still.

Tabel 5. The Effect of Mathematical Disposition to the Mathematical Communication Skill

\begin{tabular}{|c|c|c|c|c|c|c|}
\hline \multicolumn{7}{|c|}{ ANOVA $^{a}$} \\
\hline \multirow[t]{2}{*}{ Model } & & Sum of & $\mathrm{df}$ & Mean Square & $\mathrm{F}$ & Sig. \\
\hline & Regression & 420,180 & 1 & 420,180 & 20,587 & $0,000^{\mathrm{b}}$ \\
\hline \multirow[t]{2}{*}{1} & Residual & 775,595 & 38 & 20,410 & & \\
\hline & Total & 1195,775 & 39 & & & \\
\hline
\end{tabular}

From the table 4 above, it is seen that the significance is 0.000 . This value meets the criteria of Sig. $\leq 0.05$. This means that the $\mathrm{H}_{\mathrm{o}}$ is rejected. Therefore, it is concluded that there is a significant students' mathematical disposition effect to the students' mathematical communication skill. To see the correlational degree, we may consult the table below:

Tabel 6. The Correlational Degree of Mathematical Communication and Disposition Skill Model Summary ${ }^{\mathrm{b}}$

\begin{tabular}{cccccc}
\hline Model & $\mathrm{R}$ & R Square & $\begin{array}{c}\text { Adjusted R } \\
\text { Square }\end{array}$ & $\begin{array}{c}\text { Std. Error of the Durbin-Watson } \\
\text { Estimate }\end{array}$ & \\
\hline 1 & $0,593^{\mathrm{a}}$ & 0,351 & 0,334 & 4,51779 & 1,407 \\
\hline
\end{tabular}

From the above table we can see that: 
1. $\mathrm{R}^{2}=0.351$. This means that $35.1 \%$ of the data draw that there is a positive relationship between students' mathematical disposition and their mathematical communication skill.

2. $\mathrm{R}=0.593$

Based on Guilford criteria, it is concluded that the correlational degree between mathematical communication and disposition skill is on the level of medium.

\section{Discussion}

To improve mathematical communication skills seen based on learning methods that learning using problem solving in mathematics learning helps in improving students' mathematical communication skills. Likewise when viewed based on the initial mathematical ability that there are significant differences between students' mathematical communication skills at certain initial mathematical abilities. In this case the improvement of mathematical communication skills that have a high initial mathematical ability is better than those with moderate mathematical ability and low initial mathematical abilities. But there is no difference in the improvement of mathematical communication skills between those with moderate mathematical ability and low initial mathematical abilities.

This is in line with the research conducted by Triono (2016) entitled "Improving the Ability of Connections and Mathematical Communication and Middle School Student Learning Independence Using an Approach Problem Solving" shows that the achievement of communication skills and mathematical connections of students who learn with models problem solving is better than students who study conventionally. Likewise for improving communication skills and mathematical connections of students who learn with models problem solving better than students who study conventionally. Students have a positive attitude towards mathematics, learning with approaches problem solving and questions and material provided.

From the observations of researchers, the achievement and improvement of mathematical communication skills of students whose learning uses a approach problem solving there are significant differences compared to those who use ordinary learning both in terms of learning methods and the initial abilities of their students. Judging from the learning method, achievement and improvement of mathematical communication skills students who get learning problem solving are better than students who get ordinary learning. And in terms of the level of students 'initial mathematical ability, achievement and improvement of mathematical communication skills of students with high mathematical initial ability is better than students' moderate mathematical initial abilities and low initial mathematical abilities.

From the results of data processing it can be seen that the approach problem solving influences students' mathematical dispositions. Students 'mathematical dispositions are seen based on the learning method that learning that uses problem solving in mathematics learning helps in developing students' mathematical dispositions. This is in line with research by Karman (2015) entitled "Improving Comprehension and Critical Thinking Ability and Mathematical Disposition of Vocational Students through Problem Solving Approach" shows that the achievement of mathematical dispositions of students who have learning problem solving is better than students who get ordinary learning by category high achievement.

Based on the observations of researchers the mathematical disposition of students who learn using aapproach problem solving is better than those who use ordinary learning. The implication of learning that uses problem solving in mathematics learning helps develop students' mathematical dispositions. From the results of data processing related to students 'mathematical communication and disposition abilities, it can be seen that there is a significant influence of students' mathematical communication skills on their mathematical dispositions. This is shown by looking at the results of the correlation test and data processing shows that there is a link between communication skills and students' mathematical connection ability with moderate correlation.

Another research by Nurhasanah (2016) entitled "Improving Understanding Ability and Communication and Mathematical Disposition of Middle School Students throughApproaches Scientific" shows that there is an association between mathematical communication skills and 
300 Mulyasari, Rohaeti, \& Sugandi, The Application of Problem Solving Approach in Improving Junior High School Student's Mathematical Communication and Disposition Skill

mathematical dispositions of students who obtain Learning Scientific with relatively strong associations. Based on the observations of the researcher, there is a link between the students' mathematical communication and disposition abilities in the class who use problem solving and in the class that uses ordinary learning.

\section{CONCLUSION}

Based on the data analysis and the discussion of research result, it is proved that the mathematical communication skill of the students who were treated using problem solving approach is better than the students who were treated using the conventional approach. So it is with the mathematical disposition. The mathematical disposition of the students who were treated using problem solving approach is better than the students who were treated using the conventional approach. Furthermore, it is also proved that there is a relationship between the skill of mathematical disposition and mathematical communication on the category of medium.

Based on the conclusion and the research result, the researcher would like to state some suggestions, they are: (1) The problem solving approach should be applied in mathematics learning, especially in the essential topic. (2) The subject of this research is very narrow, so it is appropriately needed for future researchers to do research on more comprehensive subject. Besides, it is possible to do further research on contextual learning with larger population, school's level, and different subject.

\section{REFERENCES}

Ansari, B. I. (2004). Menumbuhkembangkan Kemampuan Pemahaman dan Komunikasi Matematik Siswa SMU melalui Strategi Think-Talk-Write. SPS UPI.

Baroody, A. J. (1993). Problem Solving, Reasoning \& Communicating, K-8: Helping Children Think Mathematically. Newyork: McMillan Publishing Company.

Karman, U. (2015). Meningkatkan Kemampuan Pemahaman dan Berpikir Kritis serta Disposisi Matematis Siswa SMK melalui Pendekatan Problem Solving. Bandung: Tesis pada Pascasarjana STKIP Siliwangi Bandung: tidak dipublikasikan.

Nurhasanah, E. K. (2016). Meningkatkan Kemampuan Pemahaman dan Komunikasi serta Disposisi Matematik Siswa SMP melalui Pendekatan Saintifik. Bandung: Tesis pada Pascasarjana STKIP Siliwangi Bandung: tidak dipublikasikan.

Rohaeti, E. E. (2004). Pembelajaran Matematika dengan Menggunakan Metode Improve untuk Meningkatkan Pemahaman dan Kemampuan Komunikasi Matematik Siswa Sekolah Lanjutan Pertama. SPS UPI.

Sugilar, H. (2013). Meningkatkan Kemampuan Berpikir Kreatif dan Disposisi Matematik Siswa Madrasah Tsanawiyah Melalui Pembelajaran Generatif. Infinity Journal, 2(2).

Sumarmo, U. (2002). Daya dan Disposisi Matematik: Apa, Mengapa dan Bagaimana Dikembangkan pada Siswa Sekolah Dasar dan Menengah. In One Day Seminar at Mathematics Major ITB. Bandung: ITB.

Triono, A. (2016). Meningkatkan Kemampuan Koneksi dan Komunikasi Matematik serta Kemandirian Belajar dengan Menggunakan Pendekatan Problem Solving. Bandung: Tesis pada Pascasarjana STKIP Siliwangi Bandung: tidak dipublikasikan. 